Behavior and Social Issues, 20, 102-117 (2011). (C) Angela Sanguinetti \& Wendy Reyes. Readers of this article may copy it without the copyright owner's permission, if the author and publisher are acknowledged in the copy and the copy is used for educational, not-for-profit purposes. doi: 10.5210/bsi.v20i0.3739

\title{
Functional Assessment of Drug Trafficking Terms: A SubSTANTIVE AND METHOdOlogical EXPANSION OF A Verbal BehaVior Research Program
}

\author{
Angela Sanguinetti ${ }^{1}$ \\ Wendy Reyes \\ University of California, Irvine
}

\begin{abstract}
Narcotics trafficking is often described in ambiguous and inaccurate terms. This is problematic because imprecise verbal behavior in relation to some state of affairs inhibits effective action with regard to those events. An innovative methodology was used to explore verbal behavior in diverse media reports following the 2001 prison escape of Joaquin "El Chapo" Guzman Loera, reputed prominent agent of the "Sinaloa Cartel." Results demonstrated that the terms "cartel," "mafia," gang," and "organization" were controlled in part by the same stimulus conditions, but which was emitted on a particular occasion was predictably related to other variables, including the speaker's affiliation, immediate verbal context, and country of publication. We conclude that more precise terminology could improve efforts to understand and curtail narcotics trafficking. We also believe this methodology should continue to be developed as it may prove useful in analyzing other terms related to important social issues.
\end{abstract}

KEYWORDS: drug trafficking, functional analysis, mentalistic terms, verbal behavior

When a speaker accurately reports, identifies, or describes a given state of affairs, he increases the likelihood that the listener will act successfully with respect to it and when the listener looks to the speaker for an extension of his own sensory capacities, or for contact with distant events, or for an accurate characterization of a puzzling situation, the speaker's behavior is most useful to him if the environmental control has not been disturbed by other variables. This is the distinction between fact and fancy, truth and fiction. (Skinner, 1957, p. 418)

Verbal behavior in the media in relation to narcotics trafficking has been "disturbed by other variables." More specifically, there are imprecise terms for

${ }^{1}$ The authors may be contacted at: angelasanguinetti@gmail.com 


\section{DRUG TRAFFICKING TERMS}

entities involved in narcotics trafficking and their internal and external agents, creating ambiguity and misinformation and inhibiting effective action. "Cartel" is the most prevalent of such terms. Researchers (Astorga, 2005; Desroches, 2005; Kenney, 2007) have argued that "cartel" is inaccurate in this context and that "network" is a superior nomination because it is associated with important properties of the phenomenon; hereafter, we adopt the term "narcotics network."

Generally, "cartel" refers to a clique conspiring to control trade through restricting the supply of a good, dividing up the market, and pushing up prices; it is a large, monopolistic, centrally controlled, bureaucratic organization (Desroches, 2005). Prevailing large "cartels," by this definition, do not control the production and distribution of narcotics in source countries (Kenney, 2007; Naylor, 2002). The use of this term sustains the incorrect assumptions that narcotics networks are enormous, unified, permanent, completely vertical in structure and tightly organized, exclusive to and isomorphic with a particular region, route, or drug market, isolated from mainstream society and from each other (Astorga, 2005; Campbell, 2009).

Mexican narcotics networks in particular are typically independent syndicates engaged in open competition, although cooperation and governmental favoritism can result in larger, quasi-monopolistic or oligopolistic networks (Astorga, 2005; Campbell, 2009). Conditions are not conducive to monopoly. Independent farmers, numbering in the tens of thousands, grow coca as part of the traditional peasant economy; manufacturers and refiners are also numerous and geographically dispersed. Large narcotics networks do not operate in complete antagonism with the state, but are indivisibly connected to various sectors of the state. They are not isomorphic with the landscape; a single narcotics network can extend across state and national borders and multiple narcotics networks often operate within the same geographical region.

"Cartel" is also used interchangeably with other terms, including "mafia" and "organization," despite dissimilar connotations. Terms that designate the agents of a narcotics network are also imprecise. The trend here is to use descriptive pseudonyms such as "El Mariposa" ("The Butterfly"), "El Fuerzas" ("The Strength"), "El Compadre" ("The Godfather"), and "Los Diablos" ("The Devils"; Astorga, 2005, p. 54), in lieu of the individual's role or position within the narcotics network.

Despite the scientific nomination of more appropriate terms (i.e., "network"), "cartel" and others may persist due to familiarity and in order to arouse emotional responses in the listener. Journalistic stories constitute the main published documentation of narcotics networks and the terminology therein is assimilated into the repertoires of the larger verbal community. Those without direct contact 


\section{SANGUINETTI \& REYES}

with the actual phenomenon must rely on media reports. In turn, the media relies heavily on law enforcement as a key source. Naylor (2002) describes "a comfortable symbiosis of objectives between law enforcement and the mass media" (p. 30). Law enforcement has a propensity to hype a target in order to secure resources from the government and the media dramatizes to lure the public with vicarious thrills.

Kenney (2007) suggested that the term "cartel," due to the vivid imagery it conveys in popular culture, serves a purpose for politicians eager to pass drugcontrol legislation, law enforcers hoping for more resources, journalists looking to sell, and fearful citizens. A behavior analytic interpretation of this hypothesis indicates a mand relation - the verbal response "cartel" is partly under the control of a characteristic consequence and a motivational state that makes that consequence reinforcing. The functional consequences might include the verbal behavior (thinking and conversation), imaginings, and, perhaps most significantly, emotional responses of the audience. Through experience with the verbal community, the speaker has learned, whether consciously or not, what the characteristic reaction is to the term and will emit it when such a reaction is desirable.

The temporally proximate behavior of the audience (i.e., their thoughts, feelings, and actions) mediates long-term effects, such as the passing of drugcontrol legislation. The condition of pending legislation would constitute a motivating operation. Pending legislation would increase the likelihood that a politician would emit an emotionally-loaded verbal response, like "cartel," by increasing the reinforcing value of a myriad of contingent reactions in the audience (e.g., fear, anger, agreement, interest, attention).

Despite theoretical speculations, we have not found any empirical explorations of terminology regarding narcotics trafficking. The general hypothesis we have outlined is that imprecise and emotionally-loaded terms are used to describe narcotics networks (tact or intraverbal relation), perhaps especially by certain parties to forward their goals (mand relation). Empirical validation of this hypothesis might be accomplished in two steps: (1) identification and description of one or more target response classes (problematic terms under some common control), and (2) the demonstration of differential response rates under varying conditions. We focused the present empirical efforts on the former, but we believe the research program outlined below may be effective in pursuing both steps. 


\section{DRUG TRAFFICKING TERMS}

\section{Methodology}

\section{The Research Program}

Skinner (1945) introduced and Leigland (1996) defended a research program to identify the conditions under which subjective, ambiguous, and hypothetical terms are used: a functional analysis of terms. In such a program, the target behavior is verbal, the manipulated conditions may consist of verbal and/or nonverbal stimuli, and the goal is the pragmatic reformulation of mentalistic psychological terms (i.e., "intention"). We adapted this program to our aim of understanding the topologies of verbal behavior in relation to narcotics networks and conditions under which this behavior occurs. Comparable to the mentalistic terms of interest to psychologists, many of these terms are subjective, ambiguous, and hypothetical.

We adapted this research program based on several considerations of the feasibility of such an analysis in the present context; however, the logic of the methodology is the same. The first dilemma was that functional analyses require the systematic manipulation of controlling variables. In the case of media discourse on narcotics networks, such control may be approximated in some ways by an elaborate experimental design, but for our purposes the naturalistic context was critical. It is not feasible to bring the media into a laboratory; therefore, an experimental functional analysis was not well-suited to our goals.

In applied behavior analysis, when a functional analysis is not practical, a non-experimental functional assessment is conducted. Information is collected regarding the occurrence of target behaviors under naturalistic conditions (i.e., varying contexts that have not been contrived and systematically implemented by an experimenter). Though less rigorous by experimental standards, functional assessments are often sufficient to identify with reasonable certainty the controlling variables of a target behavior. Dougher (1989) provided an example of a functional assessment of verbal behavior under naturalistic conditions, using archival data; specifically, he analyzed Leigland's (1989) scientific textual behavior.

Another consideration in adapting this program was that functional assessments are traditionally conducted on the behavior of an individual. We studied the verbal behavior of journalists and government officials (when directly quoted) for whom the controlling variables of the responses of interest may remain quite stable. For example, a politician advocating drug control legislation has strong motivation to describe narcotics networks in emotionally-loaded terms in all imaginable instances accessed by the media, and the media certainly always 


\section{SANGUINETTI \& REYES}

writes to sell. Isolating critical contingencies in this scenario via functional assessments of individual behavior is problematic.

Our concern was not the controlling contingencies of a given speaker's behavior per se, but the cultural contingencies common to a transnational verbal community that includes and extends beyond all those speaking in and listening to media discourse regarding narcotics networks. Adopting the radical behaviorist orientation toward studying behavior-environment relations, not individuals per se, we conceived of the terms as target behaviors and studied them across speakers. We assumed common motivating operations and a shared, rather than idiosyncratic, history with a verbal community as the critical context in which the behavior was emitted, and we strategized our data collection to strengthen this assumption.

Finally, the typical approach is to study a target behavior across varying conditions, looking for systematic differences in response rate. Because this study mainly sought to identify the target behaviors given relative stability in controlling variables, we did the reverse: We examined varying forms of verbal behavior under a relatively stable set of conditions. Taking as a case study the narcotics network associated with Sinaloa, Mexico, we conducted an exploration of terminology by surveying media publications.

In his analysis of political language, Edelman (1964) observed that "some elements are relatively stable and others highly dynamic, changing with the public issue, the conspicuous agents, the dominant domestic and foreign threat, and so on; and the changes influence the meaning of the speeches" (p. 130-131). In order to control for fluctuations in these critical conditions, we used a short date range following two significant events: the escape of Joaquin "El Chapo" Guzman Loera, the most prominent agent in the narcotics network associated with Sinaloa, and Mexican President Vicente Fox's declaration of his "war on drugs," shortly after his inauguration. These events constituted a salient set of conditions influencing the behavior of government officials and journalists, presumably in a fairly standardized manner.

\section{Data Collection and Term Selection}

We searched two databases, Access World News and LexisNexis Academic, for news articles published between January 18, 2001 and January 31, 2001. This date range was selected to immediately follow the escape of Joaquin "El Chapo" Guzman Loera from Puente Grande Federal Prison in Guadalajara, Jalisco, allegedly on January 18, 2001. It also followed shortly after the presidential inauguration of Vicente Fox, December 1, 2000, and his subsequent declaration of 


\section{DRUG TRAFFICKING TERMS}

a "war on drugs." This date range does not overlap with the following significant events that we expect may have influenced the terms used: (1) the first paramilitary group, Los Zetas, appeared in the media in 1997; (2) the September 11, 2001, terrorism act; and, (3) Osiel Cardenas Guillen's extradition and trial in the United States in 2007.

Using the database Access World News, we searched the most prominent newspaper from the capital of Mexico, Mexico City (Ciudad de Mexico, Distrito Federal DF): Reforma; the search term was "El Cartel de Sinaloa." Using LexisNexis Academic, we searched major U.S. publications, major world publications, news wire services, and web publications; the search term was "The Sinaloa Cartel." This is the most common way of referring to this particular narcotics network. Before deciding upon this search term, we tried others, including variants of El Chapo Guzman's name, which yielded fewer articles that also contained "Sinaloa Cartel." By including "cartel" in our search term, we captured the variety of terms used interchangeably (with "cartel") to refer to the same narcotics network within the same articles (a response class). Articles that did not mention the escape of Joaquin "El Chapo" Guzman Loera were not used in the analysis.

After collecting the articles, we reviewed them and compiled a comprehensive list of potential terms for analysis. We documented any term referring to the general phenomenon of narcotics trafficking, or narcotics networks and their agents. Spanish terms (and sentences when provided) were translated into English except when there was no direct translation; in such cases the Spanish term was recorded. Other information recorded included:

- Publication information: type, title, dateline, city/country of publication, prominence of article (length in words and page if newspaper article), author;

- Speaker information when term was in a direct quote: name and professional affiliation;

- Immediate verbal context of term: the full sentence in which the term was found;

- Report information: summarized message.

In an inductive fashion, we constructed categories of terms based on their form and immediate verbal context. Where terms seemed to be used in more than one category, we placed them in both. We then selected the most frequent terms for a more in-depth analysis that consisted of counting the times each term occurred across all articles as well as the number of different journals in which it 


\section{SANGUINETTI \& REYES}

occurred. We studied the sentences in which these terms appeared in order to identify possible trends for future analysis. These trends are examined in the discussion section.

\section{Results}

\section{Summary}

Publications. Our search yielded 27 articles. Two were excluded because they did not refer to the escape of Joaquin "El Chapo" Guzman Loera and another three were dismissed due to repetition (some were written by the same journalists for different publications). Analyses were performed on the remaining 22 news articles, which consisted of: 20 from printed newspapers and 2 from online news sources; 10 from Mexico, 5 from the United States (two from the New York Times, two from The Washington Post, and one from Dallas Morning News), one from Spain (El Pais out of Madrid), one from France (Le Figaro out of Paris), and 5 international news sources (three from Associated Press Worldstream, one from United Press International, and one from Agence France Presse-English (the latter two were the online articles).

Categories of terms. Based on our comprehensive list of terms and review of their form and immediate verbal context, we hypothesized four verbal response classes (responses under common stimulus control):

(1) Entity = terms referring to an illegal narcotics network;

(2) General Phenomenon = terms referring to a general phenomenon broader than a single narcotics network;

(3) Systemic Nature = terms referring to the systemic nature of the phenomenon (i.e., the involvement of agents in government positions);

(4) Prominent Agents = terms referring to important agents in a narcotics network.

Two additional categories, (5) Other Agents, and (6) Broad Social Ecological Context, are included although the terms recorded in these categories do not all belong to a common response class in the manner defined for the other categories. We present here an in-depth analysis of the "entity terms," and an overview of the other categories. 


\section{DRUG TRAFFICKING TERMS}

\section{Entity}

Narcotics network associated with Sinaloa. Since "cartel" was the search term used in data gathering, all articles contained this term. Most articles were mainly regarding the escape of Joaqu'in Guzman Loera, so in many cases the entity referenced was the narcotics network with which Guzman was reputedly affiliated. In articles published in Mexico, "cartel" appeared 12 times, in 9 different articles, referring to the narcotics network associated with Sinaloa: "Cártel de Sinaloa" (8), "Cárteles de Tijuana y Sinaloa" (1), "Cártel sinaloense" (1), "El Chapo como cabeza del cartel”("El Chapo, head of the cartel”; 1), "El Chapo Guzman...entre otros cartels" ("El Chapo Guzman...amongst other cartels"; 1). In articles published outside Mexico, "cartel" appeared in this context 13 times in 10 articles: "Sinaloa drug cartel" (6), "powerful drug cartel" (1), "drug cartel based in Culiacan, Sinaloa" (1), "Guzman's Sinaloa cartel" (1), "Sinaloa cartel" (4). This entity was also referred to as a "drug gang" 2 times in 1 article, and as an "organization" 3 times in 2 articles.

Table 1. Frequency of Entity Terms by Context and Country of Publication.

\begin{tabular}{ccccccccc} 
& \multicolumn{2}{c}{ Cartel } & \multicolumn{2}{c}{ Mafia } & \multicolumn{2}{c}{ Gang/Banda/Ring } & \multicolumn{2}{c}{ Organization } \\
\hline Network & Count & Articles & Count & Articles & Count & Articles & Count & Articles \\
\hline Sinaloa & & & & & & & & \\
In MX & 12 & 9 & 0 & 0 & 0 & 0 & 0 & 0 \\
Outside MX & 13 & 10 & 0 & 0 & 4 & 3 & 3 & 2 \\
Combined & 25 & 19 & 0 & 0 & 4 & 3 & 3 & 2 \\
Tijuana & & & & & & & & \\
In MX & 3 & 2 & 0 & 0 & 0 & 0 & 1 & 1 \\
Outside MX & 5 & 3 & 0 & 0 & 5 & 4 & & \\
Combined & 8 & 5 & 0 & 0 & 5 & 4 & 1 & 1 \\
General & & & & & & & & \\
In MX & 9 & 4 & 1 & 1 & 1 & 1 & 1 & 1 \\
Outside MX & 3 & 4 & 2 & 2 & 2 & 2 & 1 & 1 \\
Combined & 14 & 8 & 3 & 3 & 3 & 3 & 2 & 2 \\
Total & & & & & & & & \\
In MX & 23 & 10 & 1 & 1 & 1 & 1 & 2 & 2 \\
Outside MX & 23 & 12 & 2 & 2 & 7 & 4 & 3 & 2 \\
Combined & 46 & 22 & 3 & 3 & 8 & 5 & 5 & 4 \\
\hline
\end{tabular}


Narcotics network associated with Tijuana, Baja California. In articles published in Mexico, "cartel" appeared 3 times in 2 articles referring to the narcotics network associated with Tijuana, Baja California: "Los Arellano Felix...entre otros cartels" ("The Arellano Felix...amongst other cartels"; 1); "Cártel de los Arellano Félix" (1); "El Cartel de Tijuana" (1). "Organization" appeared once in this context: "Miguel Angel Felix Gallardo Organization." In articles published outside Mexico, "cartel" appeared in this context 5 times in 3 articles: "Tijuana-based Arellano Felix drug cartel" (2), "a rival cartel" (1), "Tijuana cartel" (2). This entity was also referred to as a "drug gang" 2 times in 1 article, once as a "banda" (gang) in the article published in Spain, and once as a "ring."

Narcotics networks in Mexico. In the Mexican articles, "cartel" appeared 9 times in 4 different articles referring generally to narcotics networks in Mexico: "Carteles" (6), "Carteles Mexicanos" (1), "Carteles de la Droga" (Drug Cartels; 1), “...entre otros carteles" (...amongst other cartels; 2). "Mafia" ("mafias criminales"), "bandas" (gangs) and "organization" ("multiple organizations") each appeared once in this context. In articles published outside Mexico, "cartel" appeared 3 times in 3 articles in this context: "Mexican drug cartels" (2), "cocaine cartels" (1). "Mafia" appeared 2 times in 2 articles in this context, both quoting the same statement by President Fox concerning the "mercilous war/war without mercy on/against the pernicious criminal mafias." "Gang" appeared once ("the nation's drug gangs").

\section{Other Terms Recorded}

Network. The term "network," deemed most appropriate by drug trafficking researchers (Astorga, 2005; Desroches, 2005; Kenney, 2007), did not appear in the same context as "cartel," "mafia," "organization," and "drug gang." It appeared once in a Mexican article in a direct quote from a public notary: "corruption network leaks," referring to the role of prison officials in the escape of Joaqu'in Guzman Loera. It was used twice in other news sources, both times quoting President Fox, also referring to the involvement of government employees in narcotics networks: "networks of complicity."

General phenomenon and its systemic nature. Various terms were associated with the general phenomenon of narcotics trafficking and its systemic nature (Table 2). The most frequent were: "corruption," "organized crime," "organized delinquency," "drug trafficking," "narcotrafico" and "drug trade." "Organized crime" was conveyed as broader than, but encompassing, "drug trafficking" ("battle against organized crime and drug trafficking;" "organized 
crime, particularly drug traffickers"), while never explicitly including government involvement ("corruption and organized crime;" "corruption, or rather structural corrosion of national institutions by organized crime"). In articles published outside of Mexico, some form of "corrupt" appeared 26 times, a higher rate than "cartel" (23); other terms that appeared more than once in this context included: "collusion" ( 2 incidences, 1 speaker), and "complicity" (3 incidences, 2 speakers).

We also looked for terms related to the broader social and ecological context of the phenomenon. Regarding the physical environment of narcotics trafficking, we found: "mountain range," "plantations of marijuana," "(drug) routes," and "narco tunnels." Regarding the social environment, President Fox was quoted as mentioning "the poverty and despair that lead to crime."

Agents. A variety of terms for prominent agents were used in the articles, many referring to Joaqu' in Guzman. Terms that occurred more than once and in more than one article were: "drug boss," "jefe," "drug lord," "leader," "kingpin," "head," "baron," "capo" and "narcotraficante," or "drug trafficker." "Capo" comes from the Mafia (short for "caporegime") where it referred to a ranking member below a "boss." "Narcotraficante" and "drug trafficker" were also used

Table 2. General Phenomenon and its Systemic Nature.

\begin{tabular}{lc}
\multicolumn{1}{c}{ Narcotics Trafficking } & Systemic Nature \\
\hline Crime & Collusion \\
Crimes against public health & Complicity \\
Delinquency & e.g., "complicity everywhere," \\
Drug trafficking & "networks of complicity" \\
Drug business & Corruption \\
Drugs & e.g., "corruption at a grand scale," \\
Illegal drug trade & "entrenched system of corruption" \\
Narcotics trafficking & Structural alliances \\
Narco in Mexico & Structural corrosion \\
Organized crime & \\
Organized, or professional, delinquency & \\
This evil & \\
Traffic of drugs & \\
Transit of drugs & \\
Transport and illegal sales & \\
Underworld & \\
\hline
\end{tabular}


more generally (e.g., "a group of narcotraficantes, allegedly linked to 'El Chapo." Mexican articles had more differentiated terminology for agents in government positions, giving their specific positions and names, and more descriptive pseudonyms for prominent agents (e.g., "El Chapo," "El Azul," "El Güero;" roughly translated: "Shorty," "Blue," and "Whitey").

Table 3. Agents.

\begin{tabular}{ll}
\multicolumn{1}{c}{ Prominent } & \multicolumn{1}{c}{ Other } \\
\hline Capo & 1 million presumed criminals \\
Captain & Army \\
Delinquent/criminal/convict & Assassins \\
Drug Baron & Bribed prison officials \\
Drug Boss/Jefe & Colleagues \\
Drug Kingpin & Contacts \\
Drug Lord & Distributors \\
Drug trafficker/narcotraficante & Drug trafficker/narcotraficante \\
Head & Elements of anti-forces \\
Kind of air traffic controller & Employees \\
Leader & Friends of Guzman \\
Lieutenant & Gunmen \\
Messiah & Hand of organized crime \\
Narco & Hit team \\
& Member \\
& Narco \\
& Outfit of followers \\
& Rivals \\
& Sellers \\
& Street gang members \\
\hline
\end{tabular}




\section{DRUG TRAFFICKING TERMS}

\section{Discussion}

"That a term masquerades as description while appraising and condensing doubtless heightens its emotional impact" (Edelman, 1964, p. 116). This observation applies to many of the terms found in this study. As conveyed in our literature review, narcotics networks are extremely complex, made up of thousands of agents and a myriad of processes, including management, production, manufacture, distribution, sales, and protection, as well as critical physical environmental features and a broader social system.

Even though the event of Guzman's escape highlighted the participation of government employees, the articles, especially outside Mexico, were relatively nonspecific and less creative in describing this matter (e.g., 26 incidences of "corrupt(ion)"). This is problematic considering the degree of involvement of government employees (e.g., "legacy of corruption," "entrenched corruption," "entrenched system of corruption," "corruption at a grand scale," complicity everywhere," "networks of complicity," "structural corrosion of national institutions"). There was a similar lack of specificity regarding less prominent civilian agents, especially in articles published outside Mexico. This is also troubling given the extent of this involvement (e.g., "1 million presumed criminals," "army").

We now turn to the ideas gleaned about the possible "meanings" or "reasons" for the terms we found - a more traditional functional assessment. Based on our theoretical interpretation above, controlling variables should be restricted to the most relevant environmental conditions for verbal behavior to be most effective; this is the practice in the scientific verbal community. We will consider several types of relations indicated in the data that are irrelevant and inhibit effective action with respect to narcotics networks.

\section{Audience and Mand Relations}

Since we did not have access to the reinforcement history of the speakers or the consequences of their verbal behavior, we cannot verify that any of these terms were controlled by emotional reactions in the audience; although our interpretations are that the conditions were ripe. The metaphorical language we found is perhaps more convincing in this regard than the more common terms, such as "cartel," which are well-established throughout the verbal community as tacts and intraverbals. A few examples will be given that likely evoke different responses and have interesting implications regarding characteristics of the Mexican versus international audiences. 


\section{SANGUINETTI \& REYES}

In Mexican articles, excluding direct and indirect quotes of government officials, there were more terms with positive connotations. One journalist wrote: "Joaquin Guzman Loera recently starred in a Hollywood escape." Guzman was also referred to once as " El Chapo,' farmer and rancher." This is in stark contrast to other comments, including President Fox's announcement that his administration intended to "eradicate this evil." Fox was named 26 times in Mexican articles compared to 42 times in articles published outside Mexico. These findings are unsurprising when one considers that " 1 million presumed criminals" helped make up the audience of the Mexican journalists.

\section{Intraverbal Relations}

Intraverbal relations were indicated in the contexts of four entity terms. Intraverbal relations are strengthened when other sources of control are weak; they are minimized when a verbal response is brought under more precise stimulus control. In articles published outside Mexico, all three instances of "cartel" referencing narcotics networks in general were accompanied by some mention of money: "taking bribes from a Mexican drug cartel," "Mexican drug cartels -- well entrenched, enormously wealthy," "accused of being bought off by the cocaine cartels." "Cartel" may be associated with wealth, thereby strengthening it in this context, increasing the likelihood of this response over "organization" or "gang," both of which are less evocative of "wealth" or "bribery."

Four of the five instances of "organization" were in the context of an intelligent act: "organization's efforts to infiltrate law enforcement," "the organization's profits could have been used to grease the way for Mr. Guzman's escape," "(cartels) are multiple organizations that operate with a large leeway because they are able to act outside the law due to their many resources." "Organization" and "resource" are intraverbally related. An intelligent act may strengthen the response "organization" over another response in the same class, such as "gang," which is typically associated with acts of violence rather than intelligence.

Seven out of eight incidences of "gang/band/ring" referring to a narcotics network were in the context of an act of violence or aggression: "drug gangs had taunted the new government," "shootout between Guzman's drug gang and a rival cartel," "a rival drug gang tried to rub him out," "the gang's gunmen fired on his car," "in a crossfire of rival gangs," "put the bands at the same time and place to kill the Cardinal," "brutal enemies, particularly a rival Tijuana ring led by the Arellano-Felix brothers." This last example may involve another intraverbal 


\section{DRUG TRAFFICKING TERMS}

relation between "ring" and "led," over synonyms, such as "headed" or "controlled," because of the common term "ring leader."

There were many terms related to the military, including "army," "captain," and "lieutenant." These responses might be metaphorical extensions based on similar properties: "(drug bosses are) fortifying a sophisticated, well-armed outfit of employees who have been trained with military-like discipline." They might also involve intraverbal relations based on the highly publicized "war on drugs" and mand relations promoting support for this "war."

\section{Conclusions}

Precise terminology enables effective action. Strengthening precise terminology requires first the identification of current insufficiencies in the language. Second, terms that are inaccurate or insufficient should be replaced, either by existing terms that are suitable, or by arbitrary nominations that restrict the controlling conditions to the most relevant features of the phenomenon. Even when appropriate terms are available, imprecise or metaphorical language may persist in the media due to its familiarity and function in arousing emotional responses in an audience, therefore education and dissemination of appropriate terms is critical. In the same way that racist and sexist terms fade out as they are replaced with neutral and inclusive language, the adoption of scientific terms for the parties and processes of narcotics trafficking will likely require a sociocultural climate that recognizes the inaccuracies and unfair implications of existing terms.

The motivated "misuse" of terms (consciously done or not) is not the most important problem to tackle via changing the contingency control in this verbal community (beginning with the media, law enforcement, and politicians). There are two angles of approach to the problem. The one taken here was to work to illuminate the sensationalism surrounding a few key agents via emotionallyloaded terminology, with the ultimate goal of reducing it.

The propagation of inappropriate terms is also due to insufficient understanding of the social, ecological, and historical contexts of narcotics trafficking. Psychologists should recognize the problem as one of traditional mentalistic explanatory practices. The typical approach from the fields of law and criminology focuses on the "who" and "how" of drug trafficking rather than the "why." This focus results in models that identify individuals and elusive entities rather than social and physical features of the external controlling environment. These models in turn perpetuate an approach to intervention that relies on targeting individuals for punishment rather than targeting the environment with innovative solutions based on antecedent control strategies (Skinner, 1971). 


\section{SANGUINETTI \& REYES}

Shifting the focus to contingencies of reinforcement and relevant histories might illuminate points of entry for practical and socially responsible interventions.

\section{References}

Astorga, L. (2005). El siglo de las drogas: El narcotrafico, del porfiriato al nuevo milenio. Mexico, DF: Plaza Janes.

Campbell, H. (2009). Drug war zone: Frontline dispatches from the streets of El Paso and Juarez. Texas: The University of Texas Press.

Desroches, F.J. (2005). The crime that pays: Drug trafficking and organized crime in Canada. Toronto: Canadian Scholars Press Inc.

Dougher, M. J. (1989) A functional analysis of a behavior analyst's functional analysis. The Analysis of Verbal Behavior, 7, 19-23.

Edelman, M. (1964). The symbolic uses of politics. University of Illinois Press.

Kenney, M. (2007). The architecture of drug trafficking: Network forms of organization in the Columbian cocaine trade. Global Crime, 8, 233-259.

Leigland, S. (1996). The functional analysis of psychological terms: In defense of a research program. The Analysis of Verbal Behavior, 13, 105-122.

Naylor, R. T. (2002). Wages of crime: Black markets, illegal finance, and the underworld economy. Cornell University Press.

Skinner, B. F. (1945). The operational analysis of psychological terms. Psychological Review, 52, $270-277$.

Skinner, B. F. (1957). Verbal behavior. New York: Appleton-Century-Crofts.

Skinner, B. F. (1971). Beyond freedom and dignity. New York: Knopf.

\section{Data Sources}

(2001, January 22). Mexique: Evasion d'un baron de la drogue. Le Figaro: Paris, France. Retrieved from LexisNexis Academic database.

(2001, January 22). Associated Press Worldstream, International news. Retrieved from LexisNexis Academic database.

Aznarez, J.J. (2001, January 30). Fuga con escolta policial en Mexico. El Pais, p. 2. Retrieved from LexisNexis Academic database.

Escaped Mexican drug boss remains at large. (2001, January 21). United Press International. Retrieved from LexisNexis Academic database.

Gutiérrez, M. (2001, January 28). Los dominios de Joaquín Guzmán. Reforma, p. 4. Retrieved from Access World News database.

Guzmán, I. \& Gutiérrez, M. (2001, January 25). Instala la PFP retenes en busca de 'El Chapo'Tienden autoridades cerco en el Pacífico Se ampara ex director del penal de máxima seguridad de Puente Grande, en Jalisco, y dos custodios. Reforma. Retrieved from Access World News database.

Iliff, L. (2001, January 21). Mexican drug trafficker apparently escapes prison. The Dallas Morning News, p. 19A. Retrieved from LexisNexis Academic database.

Jordan, M. (2001, January 21). Leading Mexican drug trafficker escapes from prison. The Washington Post, p. A3-A4. Retrieved from LexisNexis Academic database. 


\section{DRUG TRAFFICKING TERMS}

Lizárraga, D. (2001, January 25). Estiman que Fox no tiene proyecto 'sólo discursos'—Advierten a Fox que cometió un grave error al mantener en sus puestos a mandos medios y bajos de la Seguridad Nacional "El problema no sólo es la falta de experiencia a nivel nacional entre el primer equipo. Alguien debe decirle al Mandatario que no acabará con el narcotráfico a base de discursos; declaraciones de guerra y cruzadas nacionales lanzadas desde el micrófono" Ignacio Morales Lechuga Ex Procurador General. Reforma, p. 4. Retrieved from Access World News database.

Martin del Campo, M. (2001, January 23). Entre Paréntesis/ Punto de fuga. Reforma, p. 3. Retrieved from Access World News database.

Mexican president declares was on illegal drugs, organized crime. (2001, January 24). Agence France Presse - English. Retrieved from LexisNexis Academic database.

Navarrete, A. \& Rodriguez, D. (2001, January 21). Protagoniza 'El Chapo’un escape de película Denuncia Gobierno traición en la fuga de Puente Grande. Reforma, p. 1. Retrieved from Access World News database.

Navarrete, A., Gutiérrez, M. \& Lizárraga, D. (2001, January 27). Trasladan a custodios al DF Salen 12 del penal de Puente Grande y arraigan a dos en la PGR. Reforma, p. 4. Retrieved from Access World News database.

Reuters. (2001, January 22). Drug lord in jail break. The New York Times, p. 4. Retrieved from LexisNexis Academic database.

Rodríguez, D. (2001, January 28). Poderoso caballero... - Con una fortuna de 2 mil millones de dólares, 'El Chapo' pudo y puede comprar a cualquiera. Reforma, p. 4. Retrieved from Access World News database.

Rodríguez, S. (2001, January 27). Noche y Día/ La Guerra Contra el Crimen. Reforma, p. 2. Retrieved from Access World News database.

Ruiz, S. (2001, January 21). Consideran que la huida dificulta el Caso Posadas - Señalan que indagación pierde elementos importantes. Reforma, p. 5. Retrieved from Access World News database.

Stevenson, M. (2001, January 23). Reputed drug lord allowed outside visits, drugs at Mexico jail. Associated Press Worldstream. Retrieved from LexisNexis Academic database.

Sullivan, K. (2001, January 25). Mexicans question escape of drug lord; Fox vows action on crime, prisons. The Washington Post, p. A16. Retrieved from LexisNexis Academic database.

Susarrey, J.S. (2001, January 27). ¿Guerra ganada? Reforma, p.11. Retrieved from Access World News database.

Trejo, A. (2001, January 24). Associated Press Worldstream, International news. Retrieved from LexisNexis Academic database.

Weiner, T. (2001, January 29). Mexican jail easy to flee: Just pay up. The New York Times, p. 7. Retrieved from LexisNexis Academic database. 